\title{
Anti-inflammatory effect of the specific carbohydrate diet in children with juvenile idiopathic arthritis
}

\section{Lillemor Berntson ( $\square$ lillemor.berntson@telia.com )}

Uppsala University

\section{Research article}

Keywords: Arthritis, juvenile, anti-inflammatory diet

Posted Date: October 21st, 2020

DOI: https://doi.org/10.21203/rs.2.22438/v2

License: (c) (i) This work is licensed under a Creative Commons Attribution 4.0 International License. Read Full License 


\section{Abstract}

\section{Background}

Diet has an effect on the intestinal immune system, which may have consequences for inflammatory diseases. Specific carbohydrate diet (SCD) is an effective anti-inflammatory treatment for inflammatory bowel disease in children. We explored the anti-inflammatory effect of SCD in children with juvenile idiopathic arthritis (JIA).

Methods

Twenty-two patients with JIA (age 6.3-17.3 years), with stable, low-to-medium disease activity, were included in the study. Seven children dropped out within two weeks from the start of SCD, and fifteen patients, who completed four to five weeks of SCD, were evaluated in the final analyses. A dietician introduced parents and children to SCD with written and verbal instructions, and regular follow-ups were performed during the intervention period. Patients were studied with clinical and laboratory examinations before, during and after the intervention. In addition to conventional JIA laboratory tests, analyses were performed of short chain fatty acids in faecal samples at inclusion and after two and four weeks of SCD.

Results

SCD significantly decreased morning stiffness $(p=0.003)$ and pain $(p=0.048)$, and improved physical function assessed through the child health assessment questionnaire $(p=0.022)$. Arthritis improved in five of the seven children with arthritis at inclusion. Faecal butyrate increased significantly $(p=0.020)$.

\section{Conclusions}

SCD has significant positive effect on arthritis activity, morning stiffness, pain and physical function in children with JIA. Our results suggest that change in bacterial activity of the intestinal canal by dietary intervention may provide an effective and feasible complementary treatment for JIA.

\section{Background}

Juvenile idiopathic arthritis (JIA) is an umbrella term which describes a heterogeneous group of rheumatologic diseases that affect children; it is one of the most common chronic paediatric conditions [1]. The diagnosis encompasses seven categories, all sharing the feature of arthritis with a duration of at least six weeks and onset before the age of sixteen years [2].

The cause of the disease is considered to be multifactorial. Both the innate and the adaptive immune system have been shown to be involved in disease pathology $[3,4]$. The impact of genetic factors is heterogeneous and not dominant [5]. Environmental risk factors that have been suggested to contribute to the development of JIA include use of antibiotics at early age [6], early weaning from breastfeeding, and delivery by caesarean section [7, 8], all potentially altering the gut microbiota and intestinal immunity. Increased gut permeability has been shown in several other inflammatory diseases and in one study on JIA [9], suggesting that a dysfunctional gut barrier could increase the possibility for bacteria and other substances to interplay with the immune system, leading to a breakage of T cell tolerance. These factors may alter likelihood of JIA by influencing the development of the immune system, the integrity of the intestinal mucosal barrier, and the differentiation of immune stimulatory and regulatory cells $[10,11]$.

As in many other autoimmune diseases, like rheumatoid arthritis (RA), the composition of the bacterial flora seems to be altered in children with JIA, though results are not consistent [12-15]. In addition to studies on environmental factors and microbiota in JIA, indicating an aberrant microbial setting, there are several studies supporting an important role for gut microbiota in relation to the immune system. The microbiome affects development of the intestinal mucosal barrier and is essential for the normal generation and maturation of gut-associated lymphoid tissue [16]. The microbiome also has an impact on production of TH17 cells [17, 18].

The occurrence and function of specific phyla, genera, or families of bacteria are being studied increasingly often and immunological processes at different levels of the intestinal canal are an important matter. Analysing the concentration of shortchain fatty acids (SCFAs) in faeces is one way to study function at the colon level. SCFAs, mainly acetate, propionate, and butyrate, 
are produced by bacteria in the colon through fermentation of insoluble fibres and have been shown to have profound positive immunological effects on the intestinal immune system, in particular in the case of butyrate [19].

One possible way to affect the intestinal canal is through the diet. The specific carbohydrate diet (SCD) has been shown to have beneficial effects in inflammatory bowel disease. SCD is a nutritionally balanced diet focused on removing many complex carbohydrates such as grains, dairy products except yoghurt fermented for over 24 hours, vegetables rich in starch, and sugars, except monosaccharides like those found in honey. The digestion of complex carbohydrates relies on enzymes produced by the microbiota and large amounts of carbohydrates are believed to alter the microbiota. Monosaccharides, on the other hand, can be absorbed by enzymes in enterocytes and are therefore considered to have a lesser impact on the gut microbiota. Furthermore, most processed food is not allowed in SCD, as it contains emulsifiers and additives, proven to have a negative impact on the mucus layer in mouse intestines [20]. The diet has been shown to induce clinical and biochemical remission in paediatric Crohn's disease (CD) and ulcerative colitis [21, 22], but not complete healing [23].

The gastrointestinal tract is the largest immune system in the body, yet it is only scarcely studied in JIA. Great advances have been made in treatment of rheumatologic diseases, but not even biological agents lead to full response rates in JIA [24, 25]. The aim of this study was to explore if SCD would have an anti-inflammatory effect in children with JIA and thus provide a potential complementary treatment option.

\section{Subjects And Methods}

We recruited children and teenagers with JIA, classified in accordance with the International League of Associations for Rheumatology's criteria, at the paediatric rheumatology unit of Uppsala University Children's Hospital in Sweden, from September 2017 to September 2019. Further inclusion criteria were that patients had to be on stable treatment - i.e., there had been no change in medical treatment during the past two to three months, except for joint injections at the latest three months earlier - with a mild to moderate disease activity, no more than two active joints at inclusion, and an erythrocyte sedimentation rate (ESR) of no more than $30 \mathrm{~mm} / \mathrm{h}$. Fulfilment of the criteria for not being in remission as described by C. Wallace was also required [26]. Parents and children needed to be motivated to try a dietary intervention as a complementary treatment. Children with any gastrointestinal complaints were investigated and faecal calprotectin $<100 \mathrm{~g} / \mathrm{L}$ was required for inclusion. The primary goal was for the child to pursue the diet for four weeks or longer. Before inclusion, the families each received a recipe booklet, a list of allowed products, and a list of recommendations. An initial telephone appointment with a dietician was optional. A visit to the office of the paediatric rheumatology clinic was performed for inclusion.

After the inclusion visit, families were instructed to get familiar with what food to eat and what to avoid during a "learning period" of two weeks at most. After this two-week period, the participants were instructed to follow the SCD diet strictly for at least four weeks, with a follow-up visit after two and four weeks on SCD. At follow-ups, clinical examinations were performed, with weight measured and faecal, urine, and blood samples collected. The child health assessment questionnaire (CHAQ) was filled in [27]. Throughout the trial, the families had regular contact with and access to the dietician, by email and telephone, and also a physician, by email.

Assessments of CHAQ, juvenile arthritis disease activity score (JADAS27), morning stiffness in minutes, and pain visual analogue scale (VAS) (0-10 cm) were made at inclusion and after two and four weeks of treatment. Levels of SCFAs in faecal samples from the same occasions were analysed using a high-performance liquid chromatography machine, Agilent technology 1100 series (Agilent Technologies, Inc., Santa Clara, USA). JADAS27 (0-57) is a validated composite disease activity score often used for monitoring patients with JIA. It comprises 1$)$ the number of active joints $(0-27), 2)$ patient global assessment VAS $(0-100 \mathrm{~mm}), 3)$ physician global assessment VAS $(0-100 \mathrm{~mm})$, and 4) ESR normalised to a scale 0-10 [28]. Since conventional laboratory tests for inflammation are not very sensitive in JIA, we included a multiplex analysis of 92 inflammation-associated proteins in plasma before and after treatment (Proseek Multiplex Inflammation; Olink Bioscience, Uppsala, Sweden) [29].

The endpoints of this study were to examine whether SCD for four weeks would affect arthritis, clinical pain VAS (0-100 mm), morning stiffness (minutes), physical function assessed through CHAQ, global assessment VAS by patient/parent $(0-100 \mathrm{~mm})$, ESR, CRP, and 92 chemokines analysed with the multiplex system, or SCFAs in faecal samples. 


\section{Ethics approval}

The study was approved by the regional ethics committee in Uppsala County (Dnr 2016/263) and got additional approval from the Swedish Ethical Review Authority (Dnr 2020-01494). Verbal consent was obtained from all parents and children. Written informed consent was obtained from all parents and from children aged twelve years or older.

\section{Statistical analysis}

The Wilcoxon signed-rank test was used as the non-parametric test to estimate significance of differences in clinical and laboratory variables before and during treatment with SCD. The Hodges-Lehmann related sample analysis was used to estimate the confidence interval of the estimated median values. All tests were considered to be significant at $p<0.05$ and all statistical analyses were performed using IBM SPSS Statistics for Windows, version 25 (IBM Corp., Armonk, NY, USA).

\section{Results}

Twenty-two children with different categories of JIA were recruited to this trial and fifteen of them completed the four-week intervention; in three children, the follow-up was performed after five weeks. Four patients were in a very low disease activity state at inclusion. Only one was in remission based on the JADAS27 value for that category [28], but she had periods of morning stiffness $\geq 15$ minutes and wanted to stop treatment with methotrexate. According to the Wallace criteria, she was not in remission [26]. Demographic data are presented in Table 1. Six families dropped out of the study due to lack of motivation; in four, the child turned out not to be motivated enough, and in two, the parents were not motivated. In one family, an acute psychosocial situation stopped participation. Two of the participants did not take part in the two-week visit, because they lived far away from the clinic. Eleven (73\%) of the participants were girls and four were boys. The median age at inclusion was 13.8 years (IQR: 10.8-16.5) and median disease duration was 3.1 years (IQR: 1.7-7.6). Seven of the fifteen participants had active arthritis at time of inclusion. Faecal calprotectin levels were $0-69 \mathrm{~g} / \mathrm{L}(\min -\max$ ) at inclusion (reference value $50 \mathrm{~g} / \mathrm{L}$ ). Weight decreased with a median of $2 \%$ during the one-month intervention. Five patients were on a stable treatment with methotrexate before and during the month of intervention, three were on TNF inhibitors (two in combination with methotrexate), two were on abatacept (one in combination with methotrexate), three were treated with NSAIDs, and two received no treatment.

Five of the seven children with arthritis at inclusion did not have any clinical signs of arthritis after four to five weeks of SCD. In two children, one with enthesitis-related arthritis (a category of JIA) and one with juvenile psoriatic arthritis (another category of JIA), the inflammatory activity increased very shortly after inclusion in the study. One of them also developed a virus infection after three weeks on SCD and the JIA had worsened after five weeks on SCD.

Pain VAS (Fig. 1a) and morning stiffness (Fig. 1b) decreased and CHAQ improved significantly during the study period (Fig. 2a). JADAS27 improved, but not significantly, $p=0.065$ (Fig. 2b). Patient global assessment VAS improved, but not significantly, $p=$ 0.069. Butyrate in faecal samples in the whole cohort increased significantly during the diet period, while propionate and total levels of SCFAs increased non-significantly (Table 2).

There was no significant difference in inflammatory blood tests between baseline and week four/five (data not shown), in the total cohort, but only four participants had an ESR $>10 \mathrm{~mm} / \mathrm{h}$ at inclusion. In the seven patients with active arthritis at inclusion, the analyses of 92 inflammatory proteins with the described multiplex system showed a significant decrease in nine chemokines, TNFalpha, TRAIL, MCP-1, CX3CL1, ADA, IL10RA, IL10RB, SCF, and uPA, presented in Table 3.

\section{Discussion}

Diet affects the composition and function of the microbiota, which may have implications on health [30]. In this study, SCD as a complementary treatment in patients with JIA resulted in a significant improvement in morning stiffness, pain, and physical function. We also found a significant decrease in inflammatory proteins in the seven children with arthritis at inclusion. An increase in faecal butyrate concentration from four weeks of SCD in fifteen children coincided at a group level with improvement in clinical variables. 
Participants in this study had a low to median disease activity at inclusion; approximately half of them had morning stiffness and pain as remaining complaints from the disease, in spite of medical treatment. The clinical assessments of pain, morning stiffness, global assessment VAS, and physical function improved already after two to three weeks in the majority of participants and pointed to a positive effect from SCD. Disease activity according to JADAS27 decreased, but not significantly - which was not surprising given the low JADAS27 at inclusion. The inflammatory activity in two patients increased very shortly after inclusion in the study, and the arthritis in those two children did not respond to treatment. In the remaining five with arthritis at inclusion, no clinical sign of arthritis could be found after four/five weeks on SCD.

Laboratory analysis results of blood samples did not change significantly during the study period, but only four of the children had an $\mathrm{ESR}>10 \mathrm{~mm} / \mathrm{h}$ at inclusion. Furthermore, conventional laboratory tests for inflammation are not very sensitive in JIA [31]. However, when we studied the seven children with arthritis at inclusion, one of the most central chemokines in inflammation, TNFalpha, and its apoptosis-inducing ligand (TRAIL) decreased significantly from SCD during four weeks. Both MCP-1 and CX3CL1 also decreased. They have shown significant chemoattractant roles in recruiting inflammatory cells to synovial joints in RA and have both been associated with disease activity scores in RA [32,33]. Adenosine deaminase (ADA) is considered one of the key enzymes of purine metabolism; we can only speculate that the decreased concentration from SCD was due to the dietary change [34]. Interleukin (IL)10- and IL10R-dependent signalling modulates innate and adaptive immune responses in the murine as well as the human gastrointestinal tract. The decrease in soluble IL10RA and IL10RB from SCD in this study most likely relates to a decreased need for those receptors in a low inflammatory state [35]. The laboratory results from a multiplex system, in the seven children with arthritis at inclusion, showed an anti-inflammatory effect at a group level, raising the hypothesis that four weeks of SCD most likely had a positive impact on the inflammatory process, but not in every individual. One could also speculate that the impact in two of the children was too weak and possibly too short to affect the inflammatory process.

Our results of a significant increase in butyrate and an increasing, yet non-significant, level of SCFAs in faeces are not surprising, since fibres and starches found in fruits and vegetables are vital substrates for the production of butyrate and other SCFAs. The SCFAs are proven to have many beneficial functions, contributing to an anti-inflammatory state of the intestine. Several studies have shown that these microbial metabolites, especially butyrate - in addition to being an energy substrate for the epithelial cells of the colon - have profound effects on T cells, directly and indirectly regulating their differentiation $[19,36]$. New findings also suggest that butyrate can suppress arthritis by influencing the development and function of Breg cells in mice [37].

SCD contains large amounts of dietary fibres. Low dietary fibres may cause catabolism of the mucous layer, leading to increased permeability and allowing increased contact between luminal bacteria and the epithelium [38]. The composition of the bacterial flora, the diet of the host, and the transit time in the gut are some of the factors influencing the production of SCFAs. While the butyrate level increased in faecal samples from the participants, we do not know if butyrate is involved in regulation of inflammation in children with JIA; most likely, it plays an anti-inflammatory role.

We can only speculate that elimination of processed food, additives, and emulsifiers, and restriction of carbohydrates and dairy products play an immunological role in JIA. Processed food often contains high amounts of exogenous advanced glycation end products (AGEs), which are common in food products that have been heated. Exogenously added AGEs have been shown in animal studies to affect immune and epithelial cells by activating the receptors for AGEs in various types of cells, such as immune cells, endothelial cells, myocytes, and neurons, but studies in humans have not come that far [39]. High-fructose corn syrup (HFCS) is a popular sweetener in the food industry, for example in soda. High consumers of sodas have been shown to have an increased risk of arthritis in adults compared with low consumers [40]. HFCS is decreased in SCD compared with in a conventional diet; we lack knowledge about the occurrence of AGEs.

This study on SCD comprised only fifteen patients and the arthritis was not verified by ultrasound, which are the major weaknesses of the study. Also, children with different categories of the disease on different medical treatments were included, which may have confounded interpretation of results. It was a challenge to coordinate inclusion of a patient with a period of two/three months of a stable, low to median inflammatory state. Also, it would have been preferable to have a control group, which was difficult to organise in practice.

Making the home-cooked meals required in SCD was a challenge for many of the families, but the fairly rapid improvement in the majority of the children motivated both parents and children. A strength of the study was that the SCD is well-described and studied

Page 5/11 
in children with inflammatory conditions in the digestive tract, as one of two diets studied in paediatric IBD. The results from this study suggest that specific carbohydrate diet may provide a promising complementary treatment modality for children with JIA. Further studies are needed to understand which children with JIA may benefit from SCD, how the diet affects the immune system, and how long-lasting any effects are.

\section{Declarations}

\section{Acknowledgements}

The author is grateful to professor Yigael Finkel and medical doctor Niklas Nyström for their support and advice regarding paediatric gastroenterology, to medical student Malin Backlund for her contribution, and to professor Arja Harila-Saari and professor Kjell Alving for commenting on the manuscript. The author is also grateful to professor David Suskind, Seattle, for his positive attitude and supportive words during planning of the study.

\section{Conflicts of interest}

The author declares no conflicts of interest.

\section{Authors' contributions}

L.B. has designed the study, drafted the work, interpreted the data, finalised the manuscript, and revised it for publication.

\section{Funding}

This work was supported by the Swedish Rheumatism Association [R-657931, R-744331, R-848441], by the Gillbergska foundation, Uppsala, Sweden, and by grants from the Department of Women's and Children's Health, Uppsala University, Uppsala, Sweden.

\section{Ethics approval}

The study was approved by the regional ethics committee in Uppsala County (Dnr 2016/263). Additional ethical approval was given in 2020 by the Swedish Ethical Review Authority (Dnr 2020-01494). Verbal consent was obtained from all parents and children. Written informed consent was obtained from all parents and from children aged twelve years or older.

\section{References}

1. Berntson L, Andersson Gare B, Fasth A, Herlin T, Kristinsson J, Lahdenne P, et al. Incidence of juvenile idiopathic arthritis in the Nordic countries. A population based study with special reference to the validity of the ILAR and EULAR criteria. J Rheumatol. 2003;30:2275-82.

2. Petty RE, Southwood TR, Manners P, Baum J, Glass DN, Goldenberg J, et al. International League of Associations for Rheumatology classification of juvenile idiopathic arthritis: second revision, Edmonton, 2001. J Rheumatol. 2004;31:390-2.

3. van Loosdregt J, van Wijk F, Prakken B, Vastert B. Update on research and clinical translation on specific clinical areas from biology to bedside: Unpacking the mysteries of juvenile idiopathic arthritis pathogenesis. Best Pract Res Clin Rheumatol. 2017;31:460-75.

4. Ramanathan K, Glaser A, Lythgoe H, Ong J, Beresford MW, Midgley A, et al. Neutrophil activation signature in juvenile idiopathic arthritis indicates the presence of low-density granulocytes. Rheumatology (Oxford). 2018;57:488-98.

5. Hinks A, Cobb J, Marion MC, Prahalad S, Sudman M, Bowes J, et al. Dense genotyping of immune-related disease regions identifies 14 new susceptibility loci for juvenile idiopathic arthritis. Nat Genet. 2013;45:664-9.

6. Arvonen M, Virta LJ, Pokka T, Kroger L, Vahasalo P. Repeated exposure to antibiotics in infancy: a predisposing factor for juvenile idiopathic arthritis or a sign of this group's greater susceptibility to infections? J Rheumatol. 2015;42:521-6.

7. Kindgren E, Fredrikson M, Ludvigsson J. Early feeding and risk of Juvenile idiopathic arthritis: a case control study in a prospective birth cohort. Pediatr Rheumatol Online J. 2017;15:46. 
8. Kristensen K, Henriksen L. Cesarean section and disease associated with immune function. J Allergy Clin Immunol. 2016;137:587-90.

9. Picco P, Gattorno M, Marchese N, Vignola S, Sormani MP, Barabino A, et al. Increased gut permeability in juvenile chronic arthritides. A multivariate analysis of the diagnostic parameters. Clin Exp Rheumatol. 2000;18:773-8.

10. Arvonen M, Berntson L, Pokka T, Karttunen TJ, Vahasalo P, Stoll ML. Gut microbiota-host interactions and juvenile idiopathic arthritis. Pediatr Rheumatol Online J. 2016;14:44.

11. Verwoerd A, Ter Haar NM, de Roock S, Vastert SJ, Bogaert D. The human microbiome and juvenile idiopathic arthritis. Pediatr Rheumatol Online J. 2016;14:55.

12. van Dijkhuizen EHP, Del Chierico F, Malattia C, Russo A, Pires Marafon D, Ter Haar NM, et al. Microbiome Analytics of the Gut Microbiota in Patients With Juvenile Idiopathic Arthritis: A Longitudinal Observational Cohort Study. Arthritis Rheumatol. 2019;71:1000-10.

13. Tejesvi MV, Arvonen M, Kangas SM, Keskitalo PL, Pirttila AM, Karttunen TJ, et al. Faecal microbiome in new-onset juvenile idiopathic arthritis. Eur J Clin Microbiol Infect Dis. 2016;35:363-70.

14. Di Paola M, Cavalieri D, Albanese D, Sordo M, Pindo M, Donati C, et al. Alteration of Fecal Microbiota Profiles in Juvenile Idiopathic Arthritis. Associations with HLA-B27 Allele and Disease Status. Front Microbiol. 2016;7:1703.

15. Stoll ML, Kumar R, Morrow CD, Lefkowitz EJ, Cui X, Genin A, et al. Altered microbiota associated with abnormal humoral immune responses to commensal organisms in enthesitis-related arthritis. Arthritis Res Ther. 2014;16:486.

16. Kamada N, Seo SU, Chen GY, Nunez G. Role of the gut microbiota in immunity and inflammatory disease. Nat Rev Immunol. 2013;13:321-35.

17. Bouskra D, Brezillon C, Berard M, Werts C, Varona R, Boneca IG, et al. Lymphoid tissue genesis induced by commensals through NOD1 regulates intestinal homeostasis. Nature. 2008;456:507-10.

18. Ivanov, II, Honda K. Intestinal commensal microbes as immune modulators. Cell Host Microbe. 2012;12:496-508.

19. Furusawa Y, Obata Y, Fukuda S, Endo TA, Nakato G, Takahashi D, et al. Commensal microbe-derived butyrate induces the differentiation of colonic regulatory T cells. Nature. 2013;504:446-50.

20. Chassaing B, Koren O, Goodrich JK, Poole AC, Srinivasan S, Ley RE, et al. Dietary emulsifiers impact the mouse gut microbiota promoting colitis and metabolic syndrome. Nature. 2015;519:92-6.

21. Suskind DL, Cohen SA, Brittnacher MJ, Wahbeh G, Lee D, Shaffer ML, et al. Clinical and Fecal Microbial Changes With Diet Therapy in Active Inflammatory Bowel Disease. J Clin Gastroenterol. 2018;52:155-63.

22. Burgis JC, Nguyen K, Park KT, Cox K. Response to strict and liberalized specific carbohydrate diet in pediatric Crohn's disease. World J Gastroenterol. 2016;22:2111-7.

23. Wahbeh GT, Ward BT, Lee DY, Giefer MJ, Suskind DL. Lack of Mucosal Healing From Modified Specific Carbohydrate Diet in Pediatric Patients With Crohn Disease. J Pediatr Gastroenterol Nutr. 2017;65:289-92.

24. Shepherd J, Cooper K, Harris P, Picot J, Rose M. The clinical effectiveness and cost-effectiveness of abatacept, adalimumab, etanercept and tocilizumab for treating juvenile idiopathic arthritis: a systematic review and economic evaluation. Health Technol Assess. 2016;20:1-222.

25. Glerup M, Rypdal V, Arnstad ED, Ekelund M, Peltoniemi S, Aalto K, et al. Long-term outcomes in juvenile idiopathic arthritis: 18 years of follow-up in the population-based Nordic Juvenile Idiopathic Arthritis (JIA) cohort. Arthritis Care Res (Hoboken). 2019.

26. Wallace CA, Giannini EH, Huang B, Itert L, Ruperto N. American College of Rheumatology provisional criteria for defining clinical inactive disease in select categories of juvenile idiopathic arthritis. Arthritis Care Res (Hoboken). 2011;63:929-36.

27. Singh G, Athreya BH, Fries JF, Goldsmith DP. Measurement of health status in children with juvenile rheumatoid arthritis. Arthritis Rheum. 1994;37:1761-9.

28. Consolaro A, Giancane G, Schiappapietra B, Davi S, Calandra S, Lanni S, et al. Clinical outcome measures in juvenile idiopathic arthritis. Pediatr Rheumatol Online J. 2016;14:23.

29. Assarsson E, Lundberg M, Holmquist G, Bjorkesten J, Thorsen SB, Ekman D, et al. Homogenous 96-plex PEA immunoassay exhibiting high sensitivity, specificity, and excellent scalability. PLoS One. 2014;9:e95192. 
30. Barratt MJ, Lebrilla C, Shapiro HY, Gordon JI. The Gut Microbiota, Food Science, and Human Nutrition: A Timely Marriage. Cell Host Microbe. 2017;22:134-41.

31. Magni-Manzoni S, Cugno C, Pistorio A, Garay S, Tsitsami E, Gasparini C, et al. Responsiveness of clinical measures to flare of disease activity in juvenile idiopathic arthritis. Clin Exp Rheumatol. 2005;23:421-5.

32. An Q, Yan W, Zhao Y, Yu K. Enhanced neutrophil autophagy and increased concentrations of IL-6, IL-8, IL-10 and MCP-1 in rheumatoid arthritis. Int Immunopharmacol. 2018;65:119-28.

33. Liou LB, Tsai WP, Chang CJ, Chao WJ, Chen MH. Blood monocyte chemotactic protein-1 (MCP-1) and adapted disease activity Score28-MCP-1: favorable indicators for rheumatoid arthritis activity. PLoS One. 2013;8:e55346.

34. Moriwaki Y, Yamamoto T, Higashino K. Enzymes involved in purine metabolism-a review of histochemical localization and functional implications. Histol Histopathol. 1999;14:1321-40.

35. Shouval DS, Ouahed J, Biswas A, Goettel JA, Horwitz BH, Klein C, et al. Interleukin 10 receptor signaling: master regulator of intestinal mucosal homeostasis in mice and humans. Adv Immunol. 2014;122:177-210.

36. Koh A, De Vadder F, Kovatcheva-Datchary P, Backhed F. From Dietary Fiber to Host Physiology: Short-Chain Fatty Acids as Key Bacterial Metabolites. Cell. 2016;165:1332-45.

37. Rosser EC, Piper CJM, Matei DE, Blair PA, Rendeiro AF, Orford M, et al. Microbiota-Derived Metabolites Suppress Arthritis by Amplifying Aryl-Hydrocarbon Receptor Activation in Regulatory B Cells. Cell Metab. 2020;31:837-51 e10.

38. Desai MS, Seekatz AM, Koropatkin NM, Kamada N, Hickey CA, Wolter M, et al. A Dietary Fiber-Deprived Gut Microbiota Degrades the Colonic Mucus Barrier and Enhances Pathogen Susceptibility. Cell. 2016;167:1339-53 e21.

39. Snelson M, Coughlan MT. Dietary Advanced Glycation End Products: Digestion, Metabolism and Modulation of Gut Microbial Ecology. Nutrients. 2019;11.

40. DeChristopher LR, Uribarri J, Tucker KL. Intake of high-fructose corn syrup sweetened soft drinks, fruit drinks and apple juice is associated with prevalent arthritis in US adults, aged 20-30 years. Nutr Diabetes. 2016;6:e199.

\section{Abbreviations}

CHAQ: child health assessment questionnaire; CD: Crohn's disease; ESR: erythrocyte sedimentation rate; ILAR: International League of Associations for Rheumatology; JADAS27: Juvenile Arthritis Disease Activity Score 27; JIA: Juvenile idiopathic arthritis; RA: Rheumatoid arthritis; SCFA: short chain fatty acids; SCD: Specific carbohydrate diet; VAS: visual analogue scale.

\section{Tables}

Table 1. Clinical characteristics of fifteen children with juvenile idiopathic arthritis, treated with specific carbohydrate diet for four weeks. 


\begin{tabular}{|c|c|c|c|c|c|c|c|c|}
\hline $\begin{array}{l}\text { Patient } \\
\text { ID }\end{array}$ & Gender & $\begin{array}{l}\text { ILAR } \\
\text { categorya }\end{array}$ & $\begin{array}{l}\text { Age } \\
\text { at } \\
\text { onset, } \\
\text { years }\end{array}$ & $\begin{array}{l}\text { Age at } \\
\text { inclusion, } \\
\text { years }\end{array}$ & $\begin{array}{l}\text { Clinical } \\
\text { features at } \\
\text { inclusion }\end{array}$ & Treatment during study & $\mathrm{ANA}^{\mathrm{b}}$ & $\mathrm{HLA}-\mathrm{B} 27^{\mathrm{d}}$ \\
\hline 1 & $\mathrm{~F}$ & $\begin{array}{l}\text { Oligo } \\
\text { pers }\end{array}$ & 16.0 & 17.3 & $\begin{array}{l}\text { Arthritis, one } \\
\text { big joint }\end{array}$ & None & Neg & Pos \\
\hline 2 & $\mathrm{~F}$ & ERA & 14.0 & 14.3 & $\begin{array}{l}\text { Arthralgia + } \\
\text { morning } \\
\text { stiffness }\end{array}$ & NSAID & Neg & Pos \\
\hline 3 & M & $\begin{array}{l}\text { Oligo } \\
\text { pers }\end{array}$ & 2.9 & 9.0 & $\begin{array}{l}\text { Arthritis, one } \\
\text { big joint }\end{array}$ & None & Pos & $n a^{c}$ \\
\hline 4 & $\mathrm{~F}$ & $\begin{array}{l}\text { Juv } \\
\text { psoriatic }\end{array}$ & 13.6 & 16.7 & $\begin{array}{l}\text { Morning } \\
\text { stiffness }\end{array}$ & NSAID & Neg & $n a^{c}$ \\
\hline 5 & $\mathrm{~F}$ & Poly RF- & 13.6 & 16.5 & $\begin{array}{l}\text { Morning } \\
\text { stiffness }\end{array}$ & Methotrexate & Neg & $\mathrm{Neg}$ \\
\hline 6 & $\mathrm{~F}$ & Oligo ext & 3.0 & 13.8 & $\begin{array}{l}\text { Arthritis, one } \\
\text { big joint + } \\
\text { uveitis }\end{array}$ & Infliximab & $\mathrm{Neg}$ & $n a^{c}$ \\
\hline 7 & $\mathrm{~F}$ & $\begin{array}{l}\text { Oligo } \\
\text { pers }\end{array}$ & 3.2 & 11.7 & $\begin{array}{l}\text { Pain + } \\
\text { stiffness } \\
\text { after } \\
\text { physical } \\
\text { activity, post } \\
\text { uveitis }\end{array}$ & $\begin{array}{l}\text { Abatacept + } \\
\text { Methotrexate }\end{array}$ & Neg & $n a^{c}$ \\
\hline 8 & $\mathrm{~F}$ & Poly RF- & 8.0 & 10.8 & $\begin{array}{l}\text { Arthritis, one } \\
\text { big joint }\end{array}$ & Abatacept & Pos & $n a^{c}$ \\
\hline 9 & M & Poly RF- & 13.7 & 17.1 & $\begin{array}{l}\text { Arthritis, one } \\
\text { big + one } \\
\text { small joint }\end{array}$ & Methotrexate & Pos & Neg \\
\hline 10 & $\mathrm{~F}$ & $\begin{array}{l}\text { Oligo } \\
\text { pers }\end{array}$ & 10.8 & 14.4 & $\begin{array}{l}\text { Inflammatory } \\
\text { back pain }\end{array}$ & $\begin{array}{l}\text { Etanercept + } \\
\text { Methotrexate }\end{array}$ & Neg & Neg \\
\hline 11 & $\mathrm{~F}$ & $\begin{array}{l}\text { Oligo } \\
\text { pers }\end{array}$ & 5.6 & 9.5 & $\begin{array}{l}\text { Morning } \\
\text { stiffness, } \\
\text { recurrent } \\
\text { joint } \\
\text { injections }\end{array}$ & Methotrexate & Pos & $n a^{c}$ \\
\hline 12 & $F$ & $\begin{array}{l}\text { Oligo } \\
\text { pers }\end{array}$ & 3.7 & 11.2 & $\begin{array}{l}\text { Joint pain } \\
\text { after } \\
\text { physical } \\
\text { activity, post } \\
\text { uveitis }\end{array}$ & $\begin{array}{l}\text { Infliximab } \\
\text { Methotrexate }\end{array}$ & Pos & $n a^{c}$ \\
\hline 13 & $M$ & $\begin{array}{l}\text { Oligo } \\
\text { pers }\end{array}$ & 1.5 & 14.6 & $\begin{array}{l}\text { Arthritis, one } \\
\text { big joint }\end{array}$ & Methotrexate & Neg & Neg \\
\hline 14 & $F$ & $\begin{array}{l}\text { Oligo } \\
\text { pers }\end{array}$ & 5.6 & 6.3 & $\begin{array}{l}\text { Morning } \\
\text { stiffness, } \\
\text { pain }\end{array}$ & Methotrexate & Neg & $n a^{c}$ \\
\hline 15 & $M$ & ERA & 9.4 & 10.9 & $\begin{array}{l}\text { Arthritis, one } \\
\text { big joint }\end{array}$ & None & $n a^{c}$ & Pos \\
\hline
\end{tabular}

aILAR, International League of Associations for Rheumatology; oligo pers, oligoarticular persistent; ERA, enthesitis-related arthritis; juv psoriatic, juvenile psoriatic; poly RF-, polyarticular rheumatoid factor negative; oligo ext, oligoarticular extended.

${ }^{b}$ ANA, antinuclear antibodies. 
${ }^{\mathrm{c}}$ na, not analysed.

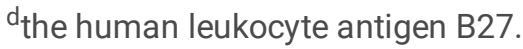

Table 2. Estimates before, compared to at four weeks of SCD treatment in fifteen children with juvenile idiopathic arthritis.

\begin{tabular}{|c|c|c|c|c|c|}
\hline $\begin{array}{l}\text { Variable } \\
\text { Md (IQR) }\end{array}$ & At inclusion & $\begin{array}{l}\text { At } 4 \\
\text { weeks } \\
\text { of SCD }\end{array}$ & $\begin{array}{l}\text { Median } \\
\text { difference }\end{array}$ & $\begin{array}{l}\text { Confidence } \\
\text { interval }^{a}\end{array}$ & p-value ${ }^{b}$ \\
\hline Pain VAS $(\mathrm{mm})^{\mathrm{c}}$ & $28(21-40)$ & $23(2-38)$ & -13.2 & $(-22.5)-(-2.0)$ & 0.048 \\
\hline Morning stiffness (min) & $30(0-60)$ & $0(0-10)$ & -27.5 & $(-40.0)-(-10.0)$ & 0.003 \\
\hline CHAQ (0-3) d & $\begin{array}{l}0.38(0.25- \\
1.0)\end{array}$ & $\begin{array}{l}0.25(0- \\
0.5)\end{array}$ & -0.25 & $(-0.44)-(-0.06)$ & 0.022 \\
\hline $\begin{array}{l}\text { Patient Global Assessment VAS Score } \\
(\mathrm{mm})\end{array}$ & $2.3(1.2-5.7)$ & $\begin{array}{l}2.0(0.2- \\
4.7)\end{array}$ & -1.4 & $(-1.8)-(-0.7)$ & 0.069 \\
\hline JADAS27 & $4.1(3.4-8.2)$ & $\begin{array}{l}3.9(0.4- \\
9.8)\end{array}$ & -2.0 & $(-0.38)-(0.5)$ & 0.065 \\
\hline
\end{tabular}

aHodges-Lehmann related sample analysis

${ }^{b}$ Wilcoxon matched-pair signed rank analysis

'Pain VAS= Pain Visual Analogue Scale

${ }^{\mathrm{d}} \mathrm{CHAQ}=$ Child Health Assessment Questionnaire

Table 3. Levels of short chain fatty acids in fecal samples before, compared to at four weeks of SCD treatment in fifteen patients with juvenile idiopathic arthritis 


\begin{tabular}{|c|c|c|c|c|c|}
\hline $\begin{array}{l}\text { SCFA } \\
\mathrm{mg} / \mathrm{g}\end{array}$ & $\begin{array}{l}\text { At inclusion } \\
\text { Md (IQR) }\end{array}$ & $\begin{array}{l}\text { At } 4 \text { weeks } \\
\text { of SCD }\end{array}$ & Median difference & Confidence interval ${ }^{a}$ & $p$-value ${ }^{b}$ \\
\hline Butyrate & $0.75(0.44-1.32)$ & $1.15(0.87-1.99)$ & 0.51 & $0.08-1.04$ & 0.02 \\
\hline Propionate & $0.87(0.50-1.01)$ & $0.94(0.59-1.30)$ & 0.16 & $(-0.01)-(0.38)$ & 0.06 \\
\hline Acetate & $3.05(2.22-3.74)$ & $3.70(2.12-5.34)$ & 0.45 & $(-0.51)-(1.07)$ & 0.33 \\
\hline Valerate & $0.10(0.04-0.15)$ & $0.11(0.06-0.17)$ & 0.02 & $(-0.05)-(0.10)$ & 0.46 \\
\hline Total & $5.36(3.61-6.77)$ & $6.59(4.23-8.54)$ & 1.14 & $(-0.19)-(2.42)$ & 0.07 \\
\hline \multicolumn{6}{|c|}{ aHodges-Lehmann related sample analysis } \\
\hline
\end{tabular}

\section{Figures}

A.

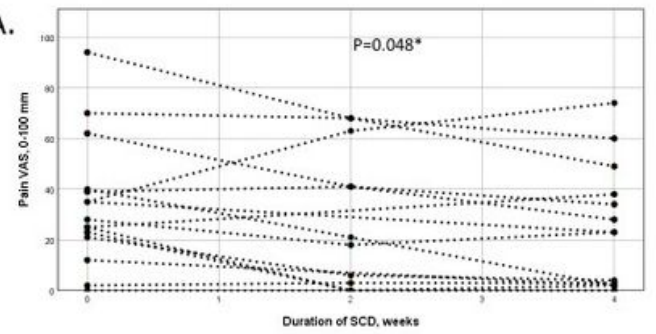

C.

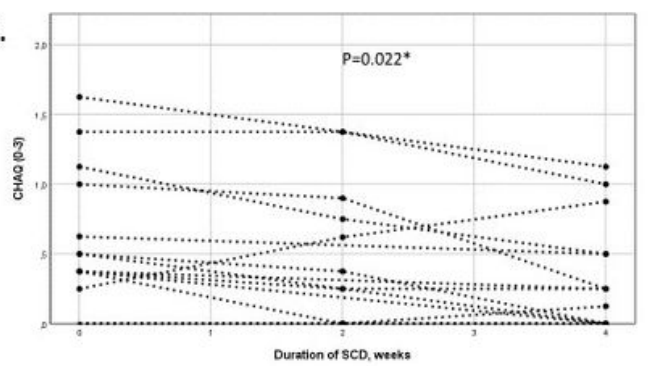

B.

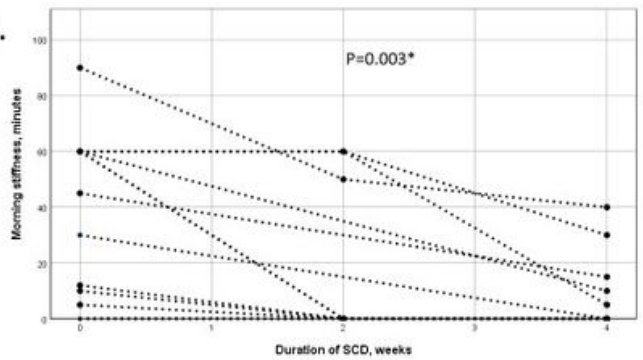

D.

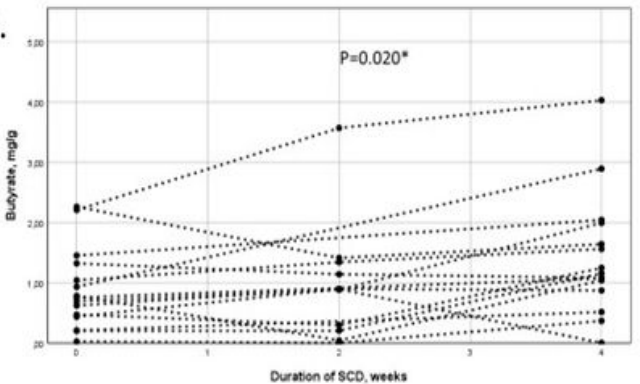

Fig. 1

\section{Figure 1}

Levels of pain on visual analogue scale (0-100 mm) (1a); Morning stiffness (minutes) (1b); Child health assessment questionnaire, CHAQ (0-3) (2a); juvenile arthritis disease activity index, JADAS27 (0-57) (2b). All at inclusion and after two and four weeks of specific carbohydrate diet in fifteen children with JIA. 